\title{
ЮРИСДИКЦІЯ АДМІНІСТРАТИВНИХ СУДІВ ЩОДО ОСКАРЖЕННЯ РІШЕНЬ, ДІЙ ЧИ БЕЗДІЯЛЬНОСТІ РОЗПОРЯДНИКА ПУБЛІЧНОЇ ІНФОРМАЦІї: ІСТОРІЯ ТА СЬОГОДЕННЯ
}

\author{
Постановка проблеми у загальному вигляді та її зв'язок із важливими наукови- \\ ми чи практичними завданнями.
}

Адміністративне судочинство є досить новим для України правовим інститутом, який, проте, натепер уже органічно увійшов у її правову систему. В умовах реформування всіх сфер суспільного життя, розбудови демократичної, правової держави пошук оптимального обсягу юрисдикції адміністративних судів, який би враховував специфіку національної правової системи, систему судоустрою в країні та передовий зарубіжний досвід у цій сфері, видається одним з актуальних напрямів наукових досліджень у науці адміністративного права і процесу.

Науковці поглиблено вивчають питання теорії, методології, практики адміністративної юрисдикції в Україні, різні аспекти організації і функціонування системи адміністративних судів, проблеми адміністративного судочинства. Однак сутність і зміст юрисдикції адміністративних судів, критерії підвідомчості справ названим органам та характеристика їхніх державно-владних повноважень не отримали достатнього наукового обгрунтування, що гальмує процес удосконалення нормативно-правової регламентації діяльності адміністративних судів та ускладнює процес вдосконалення адміністративного процесуального законодавства.

У зв'язку з цим актуальності набуває визначення особливостей адміністративного судочинства як одного з елементів механізму захисту прав особи на доступ до публічної інформації.

Аналіз останніх досліджень і публікацій, у яких започатковане розв'язання проблеми, та виділення не вирішених раніше частин загальної проблеми, яким присвячена стаття.

Певні аспекти правового забезпечення юрисдикції адміністративних судів щодо оскарження рішень, дій чи бездіяльності розпорядника публічної інформації досліджувалися в працях В.Б. Авер'янова, О.Ф. Андрійко, О.М. Бандурки, Ю.П. Битяка, А.О. Грищенка, І.П. Голосніченка, І.О. Картузової, С.В. Ківалова, О.В. Кузьменко, О.В. Нестеренко, А.О. Осадчого, В.В. Речицького, М.М. Тищенка, B.C. Цимбалюка та багатьох інших вітчизняних науковців.

Разом із тим сам факт прийняття Закону «Про доступ до публічної інформації» з багатьох об'єктивних причин позитивно не позначився на захисті прав особи на доступ до публічної інформації в порядку адміністративного судочинства. Колізії норм національного законодавства та прогалини у положеннях КАСУ ще певний час гальмували реалізацію положень Закону «Про доступ до публічної інформаціï». Поступовий розвиток і вдосконалення адміністративного процесуального законодавства є тими чинниками, які весь час актуалізують питання визначення 
юрисдикції адміністративних судів, в тому числі і стосовно оскарження рішень, дій чи бездіяльності розпорядника публічної інформації.

Постановка завдань.

Основними завданнями, розв'язанню яких присвячена ця стаття, є такі:

1) дослідити та розкрити особливості впливу розвитку національного законодавства з питань оскарження рішень, дій чи бездіяльності розпорядників публічної інформації на стан захисту прав особи в порядку адміністративного судочинства;

2) дослідити сучасний стан науково-аналітичного забезпечення адміністративного судочинства в цілому та безпосередньо з питань оскарження рішень, дій чи бездіяльності розпорядників публічної інформації.

Виклад основного матеріалу. Перш ніж розкрити особливості історії розвитку наукової думки та національного законодавства щодо юрисдикції адміністративних судів, хочемо звернути увагу на два важливі питання, які стосуються процедури оскарження в судовому порядку рішень, дій чи бездіяльності розпорядника публічної інформації:

а) розвиток адміністративного процесуального законодавства з питань оскарження рішень, дій чи бездіяльності розпорядників публічної інформації;

б) науково-аналітичне забезпечення адміністративного судочинства в цілому та безпосередньо з питань оскарження рішень, дій чи бездіяльності розпорядників публічної інформації.

Чому ці два питання є важливими для розкриття зазначеної теми статті?

Закон «Про доступ до публічної інформації» був прийнятий 13 січня 2011 року [1]. Саме в цьому нормативно-правовому акті на законодавчому рівні передбачалась можливість оскаржити в судовому порядку рішення, дії (бездіяльність) розпорядника інформації щодо надання публічної інформації. Так, пункт 3 ст. 24 Закону «Про доступ до публічної інформації» закріплює, що оскарження рішень, дій чи бездіяльності розпорядників інформації до суду здійснюється відповідно до КАСУ .

Разом із тим у прикінцевих положеннях Закону «Про доступ до публічної інформації» жодних змін у положення КАСУ не було внесено. Склалася дивна ситуація, коли нормативно-правовий акт, що передбачає нову процедуру реалізації права особи на доступ до публічної інформації та встановлює підстави і порядок оскарження рішень, дій чи бездіяльності розпорядників інформації, обмежився у перехідних положеннях лише змінами до КУпАП, Кримінального кодексу України, законів «Про оперативно-розшукову діяльність», «Про контррозвідувальну діяльність» $\mathrm{i}$ «Про авторське право і суміжні права» .

Зрозуміло, що такий підхід законодавця негативно позначився на якості та ефективності адміністративного судочинства з питань оскарження рішень, дій чи бездіяльності розпорядників публічної інформації. Наприклад, ст. 17 КАСУ (йдеться про редакцію КАСУ до 27.03.14 року), яка називалась «Юрисдикція адміністративних судів щодо вирішення адміністративних справ», пропонувала перелік публічних спорів, на які поширюється юрисдикція адміністративних судів. Серед представленого на той час переліку лише один вид спору гіпотетично і частково міг охоплювати своїм змістом справи щодо оскарження рішень, дій чи бездія- 
льності розпорядників публічної інформації. Визначався цей вид спору таким чином: «Спори фізичних чи юридичних осіб із суб’єктом владних повноважень щодо оскарження його рішень (нормативно-правових актів чи правових актів індивідуальної дії), дій чи бездіяльності».

Закон же «Про доступ до публічної інформації» оперує в основному терміном «розпорядник публічної інформації, а не терміном «суб’єкт владних повноважень». А ст. 13 Закону «Про доступ до публічної інформації» чітко перелічує осіб, які визнаються чинним законодавством розпорядниками публічної інформації. I серед таких осіб називаються не тільки суб'єкти владних повноважень, а й, наприклад, суб’єкти господарювання, які займають домінуюче становище на ринку або наділені спеціальними чи виключними правами, або є природними монополіями стосовно інформації щодо умов постачання товарів, послуг та цін на них.

Тобто положення КАСУ входили в суперечку з вимогами Закону «Про доступ до публічної інформації». Адміністративні суди були обмежені у реалізації своїх повноважень, адже були відсутні правові підстави для розгляду спорів щодо оскарження рішень, дій чи бездіяльності розпорядників публічної інформації, які належали до: 1) юридичних осіб, що фінансуються з державного, місцевих бюджетів, бюджету Автономної Республіки Крим, - стосовно інформації щодо використання бюджетних коштів; 2) суб'єктів господарювання, які займають домінуюче становище на ринку або наділені спеціальними чи виключними правами, або є природними монополіями, - стосовно інформації щодо умов постачання товарів, послуг та цін на них.

Ця правова колізія була вирішена тільки у березні 2014 року, коли частина друга ст. 17 КАСУ була доповнена пунктом 7 такого змісту: «спори фізичних чи юридичних осіб із розпорядником публічної інформації щодо оскарження його рішень, дій чи бездіяльності у частині доступу до публічної інформації» [2]. Саме з цього моменту такий вид публічних спорів можна було офіційно виділяти як самостійний і специфічний вид публічних спорів, які вправі розглядати адміністративні суди.

Хочемо звернути увагу і на те, що більшість проведених до цього часу досліджень адміністративного судочинства або взагалі оминали зазначену тему, або ж частково і фрагментарно торкалися теми оскарження в судовому порядку рішень, дій чи бездіяльності розпорядників публічної інформації.

У зв’ язку з цим слід звернути увагу і на нову редакцію КАСУ від 03.10.2017 року, яка не тільки в пункті 7 ч. 1 ст. 19 закріпила, що юрисдикція адміністративних судів поширюється на справи у публічно-правових спорах фізичних чи юридичних осіб із розпорядником публічної інформації щодо оскарження його рішень, дій чи бездіяльності у частині доступу до публічної інформації, а й передбачила багато змін щодо змісту самої процедури розгляду спорів в адміністративних судах [3]. Таким чином, велика частина наукових і науково-практичних праць, які були написані до 03.10.2017 року і присвячені проблемам адміністративного судочинства, не втративши свого теоретичного значення, втратили практичне значення для суб’єктів правозастосування і насамперед для адміністративних судів.

Наприклад, підручники та навчальні посібники з адміністративного судочинства, які були написані до 27.03.2014 року, взагалі не звертали уваги на особливості 
оскарження в судовому порядку рішень, дій чи бездіяльності розпорядників публічної інформації [4, с. 178; 5, с. 33-34; 6, с. 232-233; 7, с. 49-52].

У підручниках та навчальних посібниках з адміністративного судочинства, які були написані після 27.03.2014 року, зверталась увага на те, що з'явився новий вид спорів, що вправі розглядати адміністративні суди, але специфіка процедури розгляду таких справ все одно залишалася поза увагою авторів. Наприклад, C.В. Ківалов, І.О. Картузова і А.Ю. Осадчий у підручнику «Курс адміністративного процесуального права України (Загальна частина)» зазначають, що особливістю суб’єктного складу спорів щодо оскарження рішень, дій чи бездіяльності розпорядників публічної інформації $є$ те, що у таких спорах іноді може не бути суб'єкта владних повноважень. При цьому, наголошують науковці, навіть якщо у спорі щодо доступу до публічної інформації жодна зі сторін не є суб'єктом владних повноважень, це не виключає його публічно-правової природи. Природа таких спорів визначається публічно-правовою природою відповідних правовідносин, з яких вони виникають, адже у цих відносинах домінує публічно-правовий інтерес, їх об’єктом виступає інформація, що має суспільно значущу вагу, яка важлива не лише для окремої особи, а і для значної кількості людей, навіть якщо така інформація не належить суб’єктам владних повноважень [8, с. 136].

Тобто автори підручника теж звернули увагу на те, що суб'єктом правовідносин оскарження можуть бути не тільки суб'єкти владних повноважень, а й інші розпорядники публічної інформації. Разом із тим у підручнику не аналізувалися особливості процедури розгляду адміністративними судами спорів щодо оскарження рішень, дій чи бездіяльності розпорядників публічної інформації. Акцент в основному було зроблено на характеристиці загальних правил розгляду публічних спорів, що передбачені КАСУ.

Колектив авторів навчального посібника «Адміністративне судочинство» під редакцією Н.Б. Писаренко теж відреагував на те, що законодавець вніс зміни у ст. 17 КАСУ і передбачив такий вид публічного спору, як спір фізичних чи юридичних осіб із розпорядником публічної інформації щодо оскарження його рішень, дій чи бездіяльності у частині доступу до публічної інформації. Разом із тим характеристика таких справ обмежилася лише:

а) визначенням поняття «публічна інформація» з відповідним посиланням на Закон «Про доступ до публічної інформації»;

б) переліком суб’єктів, яких Закон «Про доступ до публічної інформації» відніс до розпорядників інформації;

в) наведенням двох прикладів судових рішень, де підставою оскарження були: в першому випадку - відмова розпорядника інформації надати інформацію, а у другому - надання розпорядником неповної інформації [9, с. 63-65].

Схожа ситуація склалася і з монографіями та науково-практичними коментарями, які були написані до 27.03.2014 року та присвячені проблемам адміністративного судочинства. У цих публікаціях відсутні будь-які посилання на Закон «Про доступ до публічної інформації» та відсутня характеристика особливостей розгляду адміністративними судами справ щодо оскарження рішень, дій чи бездіяльності розпорядників публічної інформації [10, с. 140; 11, 123-154; 12, с. 217-239; 
13, с. 147-155]. Деякі науково-практичні коментарі, що були опубліковані після 27.03.2014 року, все одно уникнули коментування пункту 7 ч. 2 ст. 17 КАСУ (нині ця редакція КАСУ втратила чинність) [14, с. 28-29].

Зважаючи на кризу, що відбувається у видавничій справі стосовно юридичної літератури, можна констатувати, що основними джерелами інформації про особливості розгляду адміністративними судами справ щодо оскарження рішень, дій чи бездіяльності розпорядників публічної інформації є матеріали практики (рішення адміністративних судів) та поодинокі наукові праці в періодичних виданнях, що додатково підкреслює актуальність наявної проблеми та свідчить про низький рівень досліджень судового захисту права особи на доступ до публічної інформації.

Адміністративне процесуальне право як частина адміністративного права України набуло повноцінного свого розвитку лише після створення системи адміністративних судів та прийняття КАСУ. Так завжди буває, що на початковому етапі формування категоріального апарату науки (це стосувалося свого часу як адміністративного процесуального права, так і інформаційного права) завжди виникали суперечки щодо змісту, співвідношення і сфери використання близьких термінів і понять. Наприклад, ст. 17 КАСУ в момент його прийняття мала назву «Компетенція адміністративних судів щодо вирішення адміністративних справ», а ст. 18 КАСУ - «Предметна підсудність адміністративних справ» [12], що давало можливість говорити про різну правову природу та зміст понять "компетенція» $\mathrm{i}$ «підсудність» адміністративних судів. 3 07.07.2010 року ст. 17 КАСУ була змінена і мала таку назву: «Юрисдикція адміністративних судів щодо вирішення адміністративних справ». Це дало привід порівнювати та співвідносити між собою поняття «компетенція», «юрисдикція» $\mathrm{i}$ «підсудність» адміністративних судів.

Взагалі питання співвідношення понять «компетенція», «юрисдикція» $\mathrm{i}$ «підсудність» адміністративних судів тривалий час було одним із проблемних у науці адміністративного права і процесу. Починаючи з 2005 року періодично з'являлися праці, в яких було намагання удосконалити термінологію адміністративного процесуального права та знайти чітке співвідношення між поняттями «компетенція», «юрисдикція» і «підсудність» адміністративних судів [15, с. 3; 16, с. 69; 17 , с. $9-21 ; 18$, с. $91 ; 19$, с. $261 ; 20$, с. 37$]$.

Чинний КАСУ підійшов до вирішення цього теоретичного питання таким чином: по-перше, назва глави вже не містить у собі два поняття, як це було в старій редакцію КАСУ до 03.10.2017 року (Глава 1 КАСУ раніше називалася «Адміністративна юрисдикція і підсудність адміністративних справ»). Нині Глава 2 КАСУ називається «Адміністративна юрисдикція»;

по-друге, чинний КАСУ не створює передумов для розмежування на теоретичному рівні понять «юрисдикція» $\mathrm{i}$ «підсудність» адміністративних судів, а чітко зазначає, що юрисдикція адміністративних судів складається 3: 1) предметної юрисдикції; 2) інстанційної юрисдикції; 3) територіальної юрисдикції (підсудності). Разом із тим кожен вид юрисдикції адміністративних судів розкривається через поняття «підсудність», що дає змогу говорити не тільки про категорії справ, які можуть розглядатися в адміністративних судах, а й уточнити, який саме адміністративний суд уповноважений розглядати певну категорію справ. У цьому сенсі 
слід погодитись з висновками, що пропонує в своїх працях С.В. Білуга. Вчений підкреслює, що під час розгляду конкретної справи у певній інстанції для визначення компетентного адміністративного суду не досить лише встановити віднесення її до адміністративної юрисдикції. Необхідно також встановити компетенцію конкретного суду щодо розгляду й вирішення публічно-правових спорів, що віднесені до адміністративної юрисдикції, тобто визначити підсудність справ адміністративного суду. Поняття ж «підсудність», на думку С.В. Білуги, використовується в КАСУ з метою правильного визначення адміністративної судової інстанції та конкретного адміністративного суду, до яких слід звертатися з адміністративним позовом [21, c. 22].

\section{Висновки та перспективи подальших розвідок.}

На підставі проведеного дослідження юрисдикції адміністративних судів щодо оскарження рішень, дій чи бездіяльності розпорядника публічної інформації можна зробити такі висновки.

1. Аналіз розвитку адміністративного процесуального законодавства 3 питань оскарження рішень, дій чи бездіяльності розпорядників публічної інформації показує, що Закон «Про доступ до публічної інформації,, встановивши у 2011 році підстави судового оскарження рішень, дій чи бездіяльності розпорядників публічної інформації, не вніс змін у КАСУ, що певний час унеможливлювало захист прав особи на доступ до публічної інформації в межах адміністративного судочинства.

Адміністративні суди були обмежені у реалізації своїх повноважень, адже були відсутні правові підстави для розгляду спорів щодо оскарження рішень, дій чи бездіяльності розпорядників публічної інформації, які належали до: 1) юридичних осіб, що фінансуються з державного, місцевих бюджетів, бюджету Автономної Республіки Крим, - стосовно інформації щодо використання бюджетних коштів; 2) суб'єктів господарювання, які займають домінуюче становище на ринку або наділені спеціальними чи виключними правами, або є природними монополіями, стосовно інформації щодо умов постачання товарів, послуг та цін на них. Ця правова колізія була вирішена тільки у березні 2014 року, коли частина друга ст. 17 КАСУ була доповнена сьомим пунктом. Саме з цього моменту такий вид публічних спорів можна було офіційно виділяти як самостійний і специфічний вид публічних спорів, які вправі розглядати адміністративні суди.

2. Аналіз науково-аналітичного забезпечення адміністративного судочинства в цілому та безпосередньо з питань оскарження рішень, дій чи бездіяльності розпорядників публічної інформації свідчить про те, що більшість проведених до цього часу досліджень адміністративного судочинства або взагалі оминали зазначену проблематику, або лише фрагментарно висвітлювали ії в контексті інших досліджень. До того ж нова редакція КАСУ від 03.10.2017 року, яка суттєво змінила зміст процедури розгляду спорів в адміністративних судах, призвела до того, що велика частина наукових і науково-практичних праць, які були написані до 03.10.2017 року і присвячені проблемам адміністративного судочинства, не втративши свого теоретичного значення, втратили практичне значення для суб'єктів правозастосування і насамперед для адміністративних судів. 


\section{Jimepamypa}

1. Про доступ до інформації : Закон України від 13.01.2011. Відомості Верховної Ради України. 2011. № 32. Ст. 314 .

2. Про внесення змін до деяких законодавчих актів України у зв'язку з прийняттям Закону України «Про інформацію» та Закону України «Про доступ до публічної інформації» : Закон України від 27 березня 2014 № 1170-VII. Відомості Верховної Ради. 2014. № 22. Ст. 816.

3. Про внесення змін до Господарського процесуального кодексу України, Цивільного процесуального кодексу України, Кодексу адміністративного судочинства України та інших законодавчих актів : Закон України від 03.10.2017 2147-VIII. Відомості Верховної Ради. 2017. № 48. Ст. 436.

4. Кузьменко О.В. Курс адміністративного процесу : навчальний посібник. Київ : Юрінком Інтер, 2012. $208 \mathrm{c}$

5. Адміністративна юстиція. Адміністративне судочинство : навчальний посібник / За заг. ред. Т.О. Коломоєць, Г.Ю. Гулєвської. Київ : Істина, 2007. 152 с.

6. Комзюк А.Т. Адміністративний процес України : навчальний посібник / А.Т. Комзюк, В.М. Бевзенко, Р.С. Мельник. Київ : Прецедент, 2007. 531 с.

7. Адміністративне судочинство : підручник / Т.О. Коломоєць, Ю.В. Пирожкова, П.С. Лютіков, I.О. Сквірський; за заг. ред. Т.О. Коломоєць. Київ : Істина, 2009. 256 с.

8. Ківалов С.В., Картузова І.О., Осадчий А.О. Курс адміністративного процесуального права України. Загальна частина : підручник. Одеса : Фенікс, 2014. 342 с.

9. Адміністративне судочинство: навчальний посібник / І.М. Балакарєва, І.В. Бойко, Я.С. Зелінська та ін.; за заг. ред. Н.Б. Писаренко. Харків : Право, 2016. 312 с.

10. Адміністративне судочинство в Україні: теорія, правове регулювання, практика : монографія / С.В. Ківалов, Л.Р. Біла-Тіунова, Д.А. Козачук та ін.; за заг. ред. С.В. Квалова і Л.Р. Білої-Тіунової. Одесса : Фенікс, 2013. 370 с.

11. Бевзенко В.М. Участь в адміністративному судочинстві України суб'єктів владних повноважень: правові засади, підстави та форми : монографія. К Київ : Прецедент, 2010. 475 с.

12. Матвійчук В.К., Хар О.І. Науково-практичний коментар до Кодексу адміністративного судочинства України. В 2-х томах. Т. 1. / За заг. ред. В.К. Матвійчука. Київ : КНТ, 2007. 788 с.

13. Кодекс адміністративного судочинства України: науково-практичний коментар / Н.О. Армаш, О.М. Бандурка, А.В. Басов та ін.; за заг. ред. А.Т. Комзюка. Київ : Прецедент; Істина. 823 с.

14. Науково-практичний коментар Кодексу адміністративного судочинства України / Н.О. Армаш, Є.В. Додін, Д.В. Журавльов та ін.; за заг. ред. С.В. Пєткова. Київ : Центр учбової літератури, 2016. 380 c.

15. Руденко А.В. Адміністративне судочинство: становлення та здійснення : дис. ...канд. юрид. наук : 12.00.07. Харків, 2005. 209 c.

16. Івашинюта В.О. Адміністративна юстиція в Україні: проблеми та перспективи. Актуальні проблеми сучасної науки і правоохоронної діяльності : матеріали підсумкової наукової конференції курсантів та студентів. Харків : Вид-во Харківського нац. ун-ту внутр. справ, 2008. С. 69-70.

17. Панченко О. Проблемні питання підсудності адміністративних справ. Вісник Вищого адміністративного суду України. 2008. № 4. С. 9-21.

18. Осадчий А.Ю. Інститут підсудності в адміністративному судочинстві. Актуальні проблеми держави і права. 2007. № 43. С. 90-94.

19. Небрат 0.О. Деякі проблеми забезпечення прав і свобод громадян у разі здійснення адміністративного судочинства в Україні. Вісник Харківського національного університету внутрішніх справ. 2008. № 41. С. $256-261$.

20. Сергейчук О. Проблеми вдосконалення законодавчих основ захисту прав людини і громадянина органами адміністративної юстиції. Вісник Вищого адміністративного суду України. 2009. № 2. C. $31-42$.

21. Білуга С.В. Предметна підсудність в адміністративному судочинстві : дис. ...канд. юрид. наук : 12.00.07. Одеса, 2012. 209 c. 


\section{Анотація}

Сибіга О. М. Юрисдикція адміністративних судів щодо оскарження рішень, дій чи бездіяльності розпорядника публічної інформації: історія та сьогодення. - Стаття.

У роботі досліджено та розкрито особливості впливу розвитку національного законодавства з питань оскарження рішень, дій чи бездіяльності розпорядників публічної інформації на стан захисту прав особи в порядку адміністративного судочинства. Констатується, що норми адміністративного процесуального права весь час відстають від норм матеріального та процедурного адміністративного права, що негативно позначається на стані судового захисту прав особи у сфері доступу до публічної інформації. Також у роботі досліджено сучасний стан науково-аналітичного забезпечення адміністративного судочинства в цілому та безпосередньо з питань оскарження рішень, дій чи бездіяльності розпорядників публічної інформації. Робиться висновок, що велика частина наукових і науково-практичних праць у зв'язку з постійними змінами національного законодавства нині втратила практичне значення для суб’єктів правозастосування і насамперед для суддів адміністративних судів.

Ключові слова: публічна інформація, судовий захист, адміністративне судочинство, юрисдикція адміністративних судів.

\section{Аннотация}

Сибига О. М. Юрисдикция административных судов по обжалованию решений, действий или бездействия распорядителя публичной информации: история и настоящее. - Статья.

В работе исследованы и раскрыты особенности влияния развития национального законодательства по вопросам обжалования решений, действий или бездеятельности распорядителей публичной информации на состояние защиты прав личности в порядке административного судопроизводства. Констатируется, что нормы административного процессуального права всё время отстают от норм материального и процедурного административного права, что отрицательно сказывается на состоянии судебной защиты прав личности в сфере доступа к публичной информации. Также в работе исследовано современное состояние научно-аналитического обеспечения административного судопроизводства в целом и непосредственно по вопросам обжалования решений, действий или бездеятельности распорядителей публичной информации. Делается вывод, что большая часть научных и научно-практических работ в связи с постоянными изменениями национального законодательства сегодня потеряла практическое значение для субъектов правоприменения и в первую очередь для судей административных судов.

Ключевые слова: публичная информация, судебная защита, административное судопроизводство, юрисдикция административных судов.

\section{Summary}

Sybiha O. M. Jurisdiction of administrative courts on appeal of decisions, actions or inactivity of public information administrator: history and nowadays. - Article.

The paper studies and covers peculiarities of the influence of the development of national legislation on the appeal of decisions, actions or inactivity of public information administrator on the state of human rights protection under administrative procedure. It is stated that the rules of administrative procedure law typically are falling behind the norms of substantive and administrative procedural law adversely affects the state of judicial protection of human rights in the sphere of access to public information. The article also examines the current state of scientific and analytical support of administrative procedure in general and in the context of appealing decisions, actions of inactivity of public information administrator. The author concludes that due to constant changes in the national legislation, a great number of academic and scientific-practical papers has lost its practical value for the subjects of law enforcement and, first of all, for judges of administrative courts.

Key words: public information, judicial protection, administrative procedure, jurisdiction of administrative courts. 